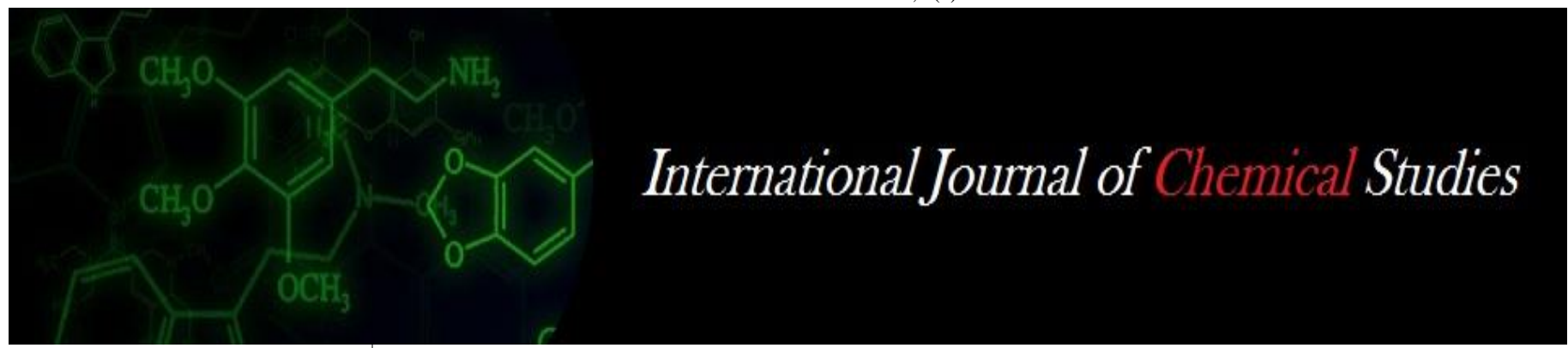

P-ISSN: 2349-8528

E-ISSN: 2321-4902

IJCS 2020; 8(1): 1264-1268

(C) 2020 IJCS

Received: 01-11-2019

Accepted: 05-12-2019

Abubaker Mohamed Outhman Department of Environmental Science, Faculty of Engineering \&Technology Sabah University, Libya

Osama Asanousi Lamma Department of Soil \& water Faculty of Agricultural, Bani Walid University, Libya

Corresponding Author:

Abubaker Mohamed Outhman Department of Environmental Science, Faculty of Engineering \&Technology Sabah University, Libya

\section{Investigate the contamination of tissue paper with heavy metals in the local market}

\author{
Abubaker Mohamed Outhman and Osama Asanousi Lamma
}

DOI: $\underline{\text { https://doi.org/10.22271/chemi.2020.v8.i1r.8426 }}$

\begin{abstract}
The study aimed to investigate the presence of some heavy metals in the different used paper tissue paper in the local market, evaluate their types in terms of their safety and highlight the risks arising from the excessive use of anonymous tissue paper. At highlighting the potential damage from the impact of the use of different tissues paper on human health in terms of the probability of the presence of heavy metals in the tissue paper product. The presence of the following metals (Cadmium, Lead, Chromium) war investigated in 20 random samples from the market where seven different types of homemade and imported brands were collected. The concentration of cadmium in all types of samples ranged from $(0.21$ - 0.05) ppm, where the highest concentration of the cadmium in the sample (A8) and the lowest concentration was in the sample (T4). The concentration of lead in all types of samples ranged from (0.01 - 0.32) ppm where the highest concentration of the lead in the sample (A9) and the lowest concentration was in the sample (A3 / A1). For the samples K2, A11 did not give absorption. The concentration of chromium in all types of samples ranged from (0.07-1) ppm where the highest concentration of the element in the sample (A4) and the lowest concentration were in the sample (A9).
\end{abstract}

Keywords: Heavy metals, tissue paper, contamination, lead, cadmium, chromium

\section{Introduction}

Human used all sources of nature in order to achieve his welfare and raise the standard of living and did not hesitate to do so in the use of all methods regardless of the possible negative consequences that may affect the environment in general and the human in particular, has resulted from the concern of the human side profit and neglect The environmental and health aspects of its activities The emergence of a number of negative phenomena in society that have an unhealthy impact on the human person himself. With the steady increase in the population, there is a need to increase the work to provide the human needs necessary such as food, energy and unnecessary, which will only increase the welfare and comfort. Therefore, many manufacturers resort to condoning the quality of the source and adopt a profitable policy, using raw materials with unhealthy sources such as recycling of solid waste and using it in industries that are disproportionate to the source of waste. One of the most important products used by humans in a large and intensive are tissue paper, which is used in many walks of life and this because of its availability in many forms and sizes and accessibility because of its licenses, and there is a wide range of products that are manufactured from tissue paper, including toilet paper, wipes Pocket, kitchen towels, tablecloths, where tissue paper are used in personal hygiene, toilet cleaners, hospitals and used in dealing with food and food where wrapped foods with tissue paper until consumed as this leads to direct contact with health and safety Human food and used after eating in cleaning. Higher plants may be used as bio-monitors for the assessment of atmospheric heavy metal pollution by means of their bio-accumulative properties (Milica Tomasevic 2004) ${ }^{[15]}$ trees can be considered to play important roles in purifying the environment and fixing heavy metals (Tong Zhang 2017) A family of four consumes the equivalent of a tree and a half a year in the form of tissue paper. Heavy elements are widely disseminated in the environment naturally or as a result of different activities of man and are exposed to them in various ways (Wilson and Pxatt 2007) ${ }^{[12]}$ The human use of these tissue paper randomly without being careful to use each type for the purpose allocated to them and thus increase the likelihood of exposure to the user potential damage from the 
presence of hazardous substances to health resulting from recycling or industry processes such as dyeing and coloring. Arsenic and mercury cause damage to the liver, kidneys and digestive tract and cause accumulation to neurological strikes (Osweiler 1996) lead is often accumulated in the liver and pancreas (George and Florance 1981) ${ }^{[11]}$ In recent years, increased awareness of the dangers to human health and the environment caused by certain processes and chemicals used in the manufacture of tissue paper products has led to multiple regulations being imposed on the industry to ensure the sustainability of their business. Since the manufacturing and recycling of paper napkins depends heavily on the use of water, it is important that the water conforms to health specifications or will lead to the production of a low-quality product that affects the health and safety of human beings and the most important pollutants and potentially dangerous in the water heavy metals due to use On the other hand, tissue paper products go through several complex manufacturing processes and use natural or chemical materials in their treatment, beautification, dyeing or coloring, and in some cases the treatment processes are uncontrolled and non-controlled. It is possible to lead to the arrival of products in the market without meeting the standards and specifications of safety and health of the consumer and thus contrary to the task for which the product was made. Also for napkins where the dyes are used in the process of coloring, these dyes may be made of materials containing some heavy metals and therefore Heavy metals are more likely to be present within the tissue component. There is a danger of these napkins cheap and widespread in the market, is that they are not safe for human health and infect users with skin infections and allergies due to the increase in the proportion of ash in them. Where the use of paper towels as paper towels to $36 \%$ and $45 \%$ as toilet paper $19 \%$ in other uses where it is clear that the extent of human treatment tissue paper, which reflects on human health if the product is less than the industrial level, which ensures the protection of the consumer from the negative impact on them.

\section{Materials and Methods \\ Study area}

Brack Alshati is located between latitude 27.53.33 north and longitude 14.28.33 east, and its population around 50,000. To the west, Alshati borders the Illizi Province of Algeria. After the 2007 administrative reorganization of districts, it borders on Nalut in northwest, Jabal al Gharbi in the north, Jufra in the east, Sabha in the southeast, Wadi al Hayaa in the south and Ghat in the southwest.

\section{Collection and preparation of tissue paper sample}

The study was carried on January 2018 on the lap of department Environmental Sciences, Faculty of Engineering \&Technology, Sebha University. The samples of tissue paper were collect from the local market of the town of Brack Alshati there are two types of tissue in market one local and out of country we selected 20 types of tissue.

Samples were taken from the common tissue paper, the market in the Brack Alshati (Libya) area of various types and were divided into three groups as follows:

1. Toilet tissue paper Symbolized by (T).
2. A group of kitchen tissue paper known as table tissue paper. Symbolized by (K).

3. A group of other uses tissue paper includes pocket tissue paper, car tissue paper and tissue paper shaving salons Symbolized by (A).

\section{Preparing samples for measurement}

1. Tissue paper samples were taken 1 gram and burn in oven for 3 hours at $500{ }^{\circ} \mathrm{C}$.

2. The samples were digested with dilute nitric acid $1.5 \%$ in a beaker $50 \mathrm{ml}$, the extract was prepared to measure the heavy metals.

3. We used Atomic Absorption Spectrophotometer 2380 Perkin-Elmer.

\section{Study Area}

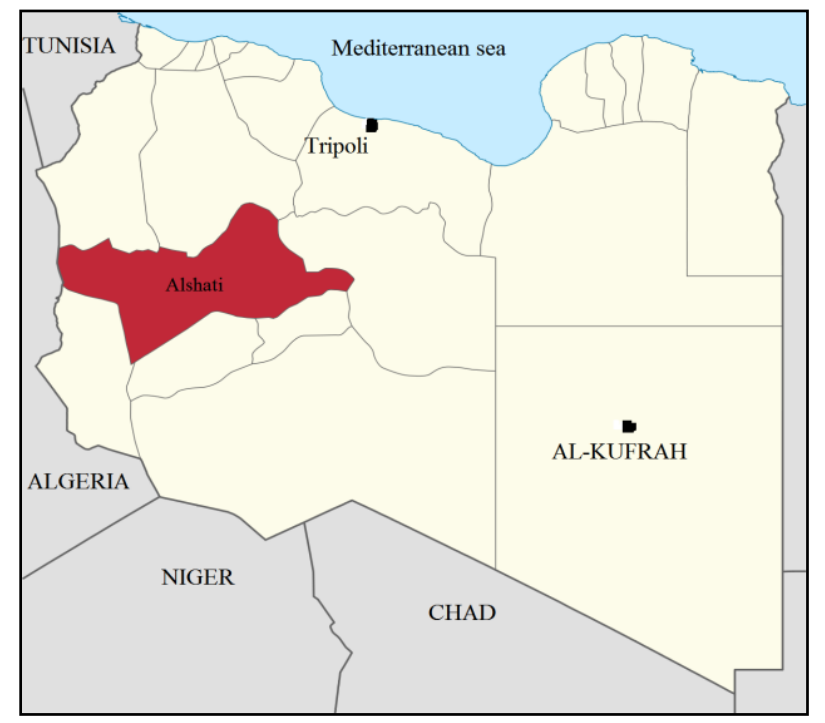

Calculations

After getting the absorption of the heavy metals under study $(\mathrm{Co}, \mathrm{Cu}, \mathrm{Pb}, \mathrm{Cd}, \mathrm{Cr}, \mathrm{Ni})$ in the samples, their concentration in the samples is calculated mathematically by the following laws: -

$\mathrm{C}=\mathrm{A} / \mathrm{K}$

$\mathrm{Cmg} / \mathrm{L}=\mathrm{C}^{*} \mathrm{~V} / \mathrm{WT}$

Where as:- $\mathrm{A}=$ Absorption, $\mathrm{C}=$ concentration, WT=Weight of sample

\section{Discussion}

The results showed that the concentrations of the heavy metals in all the three type of tissue paper are different, whereas the concentration of some heavy metals were found in tissue paper samples and some of samples don't give any results.

1. The concentrations of cadmium in all type of tissue paper: The table and (1) shown The concentration of cadmium in all types of samples ranged from $(0.21$ 0.05) ppm, where the highest concentration of the element in the sample (A8) and the lowest concentration was in the sample (T4) and K2, K3, A3, A6, A7, A9 less sensitivity of the Instrument. 
Table 1: shows the Concentration of Cadmium in samples

\begin{tabular}{|c|c|c|c|c|c|c|c|}
\hline Concentration & Sample & Concentration & Sample & Concentration & Sample & Concentration & Sample \\
\hline 0 & A6 & 0.08 & A1 & 0.1 & K1 & 0.16 & T1 \\
\hline 0 & A7 & 0.21 & A2 & 0 & K2 & 0.13 & T2 \\
\hline 0.21 & A8 & 0 & A3 & 0 & K3 & 0.16 & T3 \\
\hline 0 & A9 & 0.1 & A4 & 0.1 & K4 & 0.05 & T4 \\
\hline 0.05 & A10 & 0.08 & A1 & 0.16 & K5 & - & - \\
\hline 0.08 & A11 & 0.19 & A5 & - & - & - & - \\
\hline
\end{tabular}

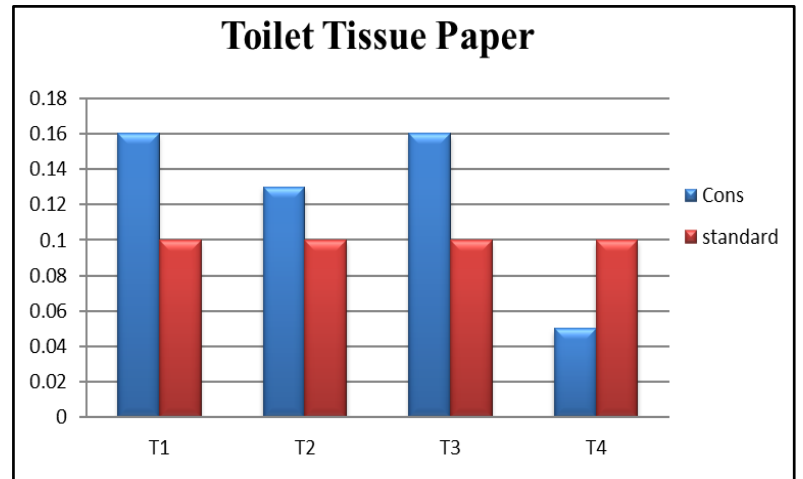

Fig 1: Shows the concentrations of cadmium in the toilet samples

Figure 1 shows that all concentrations of cadmium in the samples were higher than the allowable limit except the T4 sample was lower than the standard limit and the highest concentration was $13 \mathrm{ppm}$ in the sample $\mathrm{T} 3, \mathrm{~T} 1$.

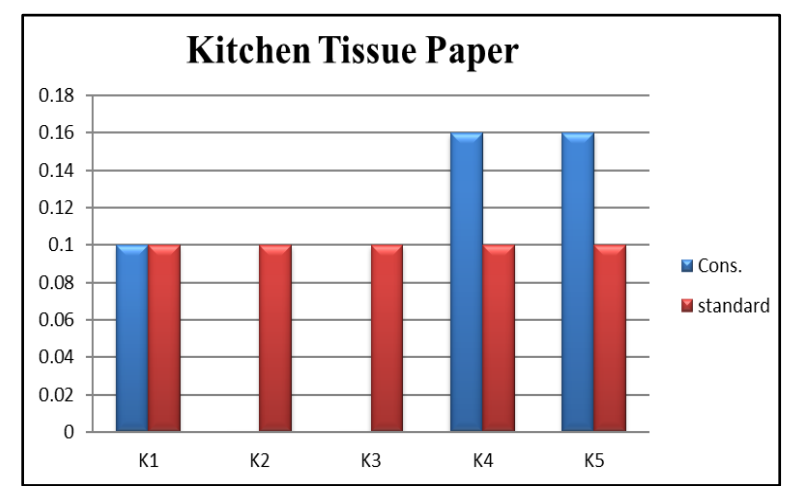

Fig 2: Shows the concentration of cadmium in kitchen tissue paper

From Figure (2) it is clear that samples K4 and K5 had a higher concentration of cadmium and the other samples did not exceed the standard limits where their concentration was $0.16 \mathrm{ppm}$.

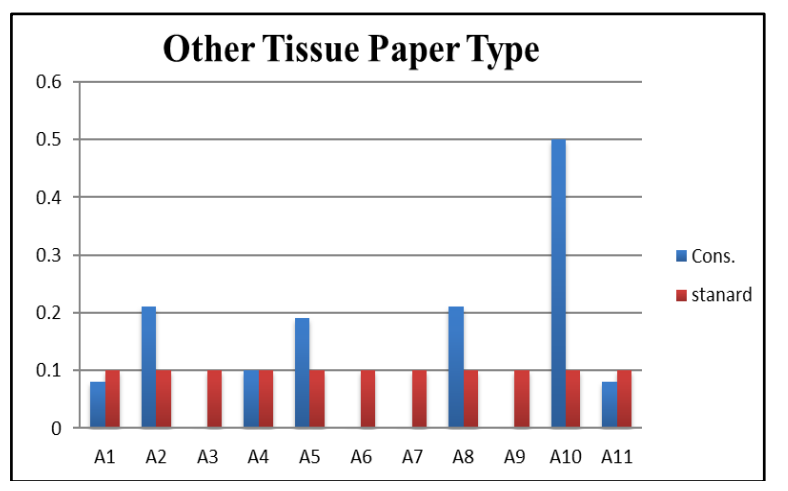

Fig 3: Shows the concentrations of cadmium in other tissue paper

Figure (3) shows the concentrations of samples A2, A5, A8 and A10. Are above limits of cadmium concentration and the highest concentration on A10 it was $0.5 \mathrm{ppm}$. The other samples were below the standard limit.

2. The concentrations of Lead in all type of tissue paper: The results shown in Table (2) and shown in the graph (4, $5,6)$ shows that the concentration of lead element in all types of samples ranged between $(0.01-0.32) \mathrm{ppm}$, where the highest concentration of the element in the sample (A9) and the lowest concentration was in the sample (A3 / A1) As for the samples K2, A11 less sensitivity of the Instrument.

Table 2: shows the concentration of lead in samples

\begin{tabular}{|c|c|c|c|c|c|c|c|}
\hline $\begin{array}{c}\text { Concentra } \\
\text { tion }\end{array}$ & $\begin{array}{c}\text { Sam } \\
\text { ple }\end{array}$ & $\begin{array}{c}\text { Concentra } \\
\text { tion }\end{array}$ & $\begin{array}{c}\text { Sam } \\
\text { ple }\end{array}$ & $\begin{array}{c}\text { Concentra } \\
\text { tion }\end{array}$ & $\begin{array}{c}\text { Sam } \\
\text { ple }\end{array}$ & $\begin{array}{c}\text { Concentra } \\
\text { tion }\end{array}$ & $\begin{array}{c}\text { Sam } \\
\text { ple }\end{array}$ \\
\hline 0.16 & $\mathrm{~A} 6$ & 0.01 & $\mathrm{~A} 1$ & 0.28 & $\mathrm{~K} 1$ & $\boldsymbol{0 . 0 7}$ & $\mathrm{T} 1$ \\
\hline 0.23 & $\mathrm{~A} 7$ & 0.1 & $\mathrm{~A} 2$ & 0 & $\mathrm{~K} 2$ & 0.16 & $\mathrm{~T} 2$ \\
\hline 0.28 & $\mathrm{~A} 8$ & 0.01 & $\mathrm{~A} 3$ & 0.25 & $\mathrm{~K} 3$ & 0.23 & $\mathrm{~T} 3$ \\
\hline 0.32 & $\mathrm{~A} 9$ & 0.23 & $\mathrm{~A} 4$ & 0.25 & $\mathrm{~K} 4$ & 0.21 & $\mathrm{~T} 4$ \\
\hline 0.12 & $\mathrm{~A} 10$ & 0.21 & $\mathrm{~A} 5$ & 0.16 & $\mathrm{~K} 5$ & - & - \\
\hline 0 & $\mathrm{~A} 11$ & - & - & - & - & - & - \\
\hline
\end{tabular}

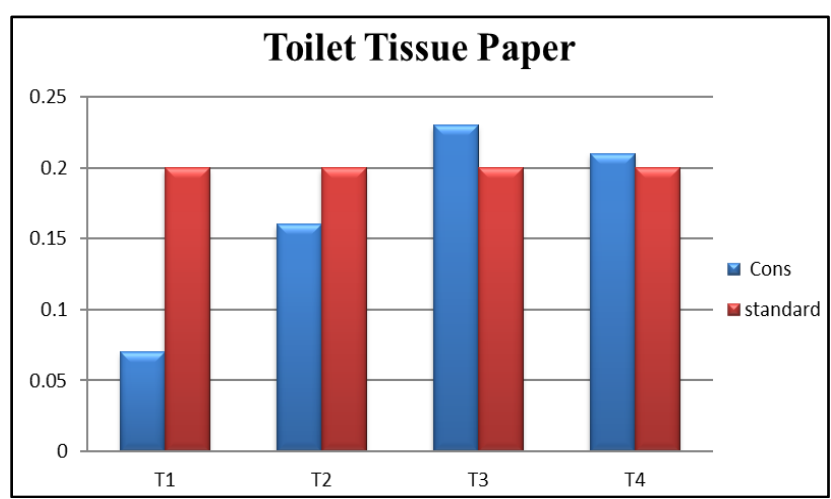

Fig 4: Shows the concentrations of Lead in the toilet tissue paper samples

The figure 4 shows that samples T3, T4 had a concentration above the limits and samples T1, T2 did not exceed the limit, where the highest concentration of lead in the T3 sample was $0.23 \mathrm{ppm}$ and the lowest concentration in the T1 sample was $0.07 \mathrm{ppm}$.

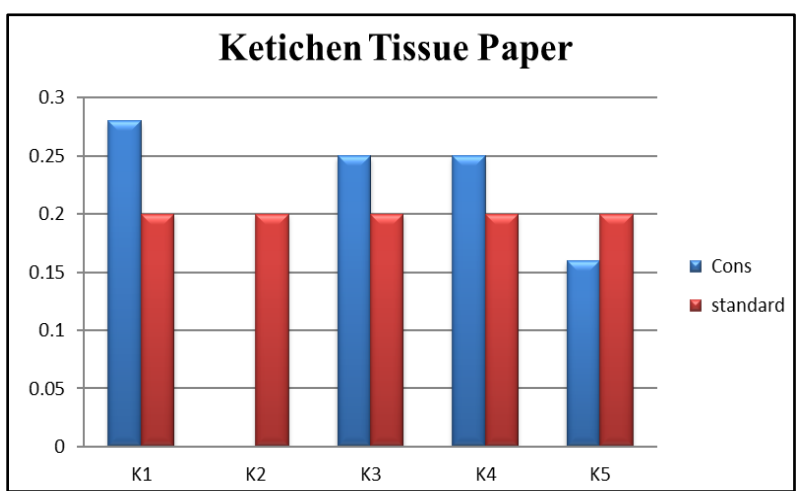

Fig 5: Shows the concentrations of Lead in the kitchen tissue paper samples 
The figure (5) shows that samples K1, K3, and K4 above the lead limit. The sample K1 had the highest concentration of lead by $0.28 \mathrm{ppm}$.

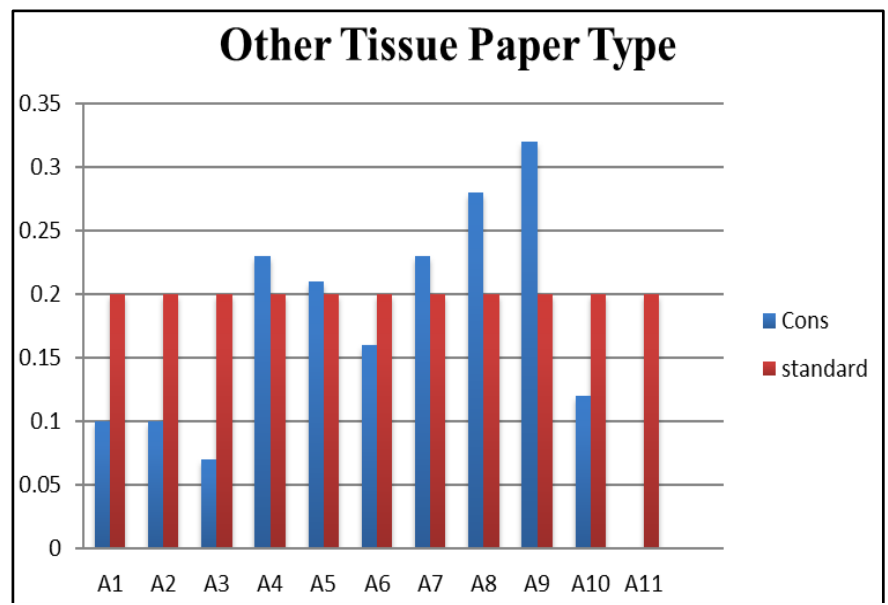

Fig 6: Shows the concentrations of Lead in the other tissue paper samples

The figure (6) that half the number of samples in other tissue paper type exceeded the limit whereas the highest concentration in the sample A9 and the concentration of lead by $0.32 \mathrm{ppm}$ and the lowest concentration of $0.07 \mathrm{ppm}$ in the sample A3.

4-The concentrations of chromium in all type of tissue paper:

The results shown in Table (3) and shown in the graphs (7, 8, 9) shows that the concentration of chrome in all types of samples ranged between $(1-0.07) \mathrm{ppm}$, where the highest concentration of the chromium in the sample (A7, A4) and the lowest concentration was in the sample (A9).

Table 3: Shows the concentration of chromium in samples

\begin{tabular}{|c|c|c|c|c|c|c|c|}
\hline $\begin{array}{c}\text { Concentra } \\
\text { tion }\end{array}$ & $\begin{array}{c}\text { Sam } \\
\text { ple }\end{array}$ & $\begin{array}{c}\text { Concentra } \\
\text { tion }\end{array}$ & $\begin{array}{c}\text { Sam } \\
\text { ple }\end{array}$ & $\begin{array}{c}\text { Concentra } \\
\text { tion }\end{array}$ & $\begin{array}{c}\text { Sam } \\
\text { ple }\end{array}$ & $\begin{array}{c}\text { Concentra } \\
\text { tion }\end{array}$ & $\begin{array}{c}\text { Sam } \\
\text { ple }\end{array}$ \\
\hline 0.57 & $\mathrm{~A} 6$ & 0.35 & $\mathrm{~A} 1$ & 0.57 & $\mathrm{~K} 1$ & $\boldsymbol{0 . 2 8}$ & $\mathrm{T} 1$ \\
\hline 1 & $\mathrm{~A} 7$ & 0.28 & $\mathrm{~A} 2$ & 0.48 & $\mathrm{~K} 2$ & 0.64 & $\mathrm{~T} 2$ \\
\hline 0.78 & $\mathrm{~A} 8$ & 0.92 & $\mathrm{~A} 3$ & 0.5 & $\mathrm{~K} 3$ & 0.25 & $\mathrm{~T} 3$ \\
\hline 0.07 & $\mathrm{~A} 9$ & 1 & $\mathrm{~A} 4$ & 0.28 & $\mathrm{~K} 4$ & 0.57 & $\mathrm{~T} 4$ \\
\hline 0.21 & $\mathrm{~A} 10$ & 0.78 & $\mathrm{~A} 5$ & 0.78 & $\mathrm{~K} 5$ & - & - \\
\hline 0.5 & $\mathrm{~A} 11$ & - & - & - & - & - & - \\
\hline
\end{tabular}

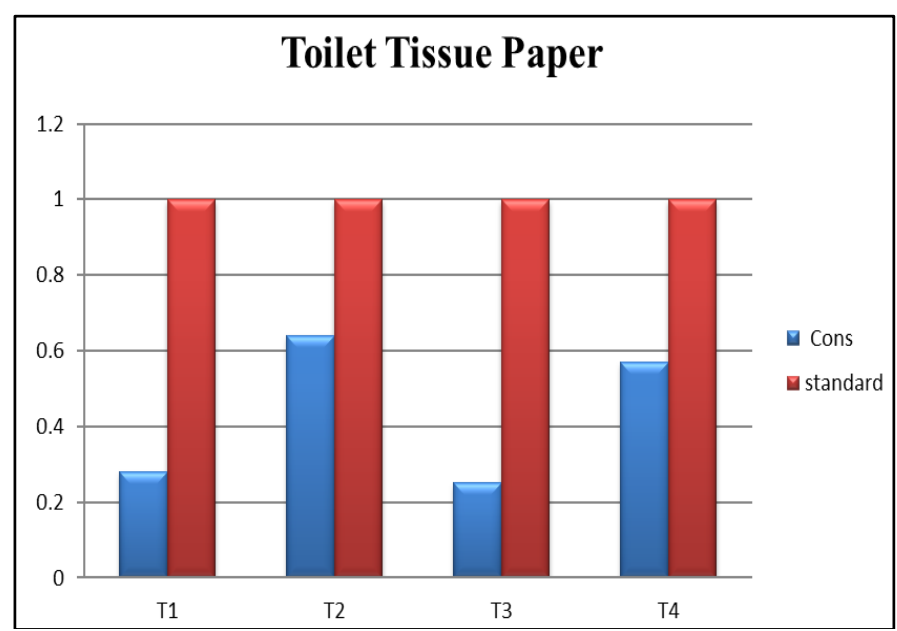

Fig 7: Shows the concentrations of chromium in the other tissue paper samples

In Fig. 7, it is clear that all samples did not exceed the standard limits of chromium so that its results ranged from the highest concentration in the $\mathrm{T} 2$ sample at $0.63 \mathrm{ppm}$ and the lowest chromium concentration in the $\mathrm{T} 3$ sample was 0.25 ppm.

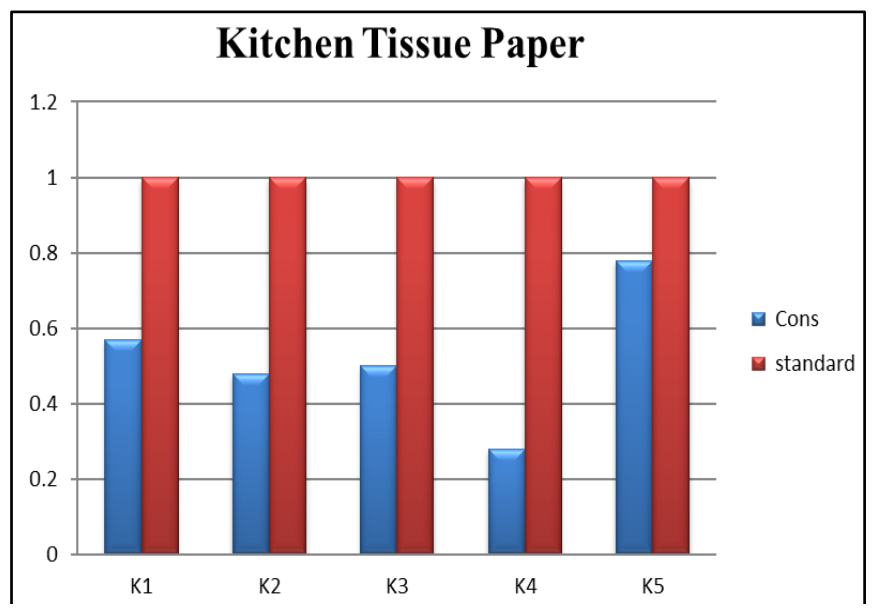

Fig 8: Shows the concentrations of chromium in the kitchen tissue paper samples

Figure (8) shows the sample concentrations for chromium; all samples did not exceed the standards limits. The highest concentration was $0.78 \mathrm{ppm}$ in sample $\mathrm{K} 5$ and the lowest concentration was ppm0.28 in sample.

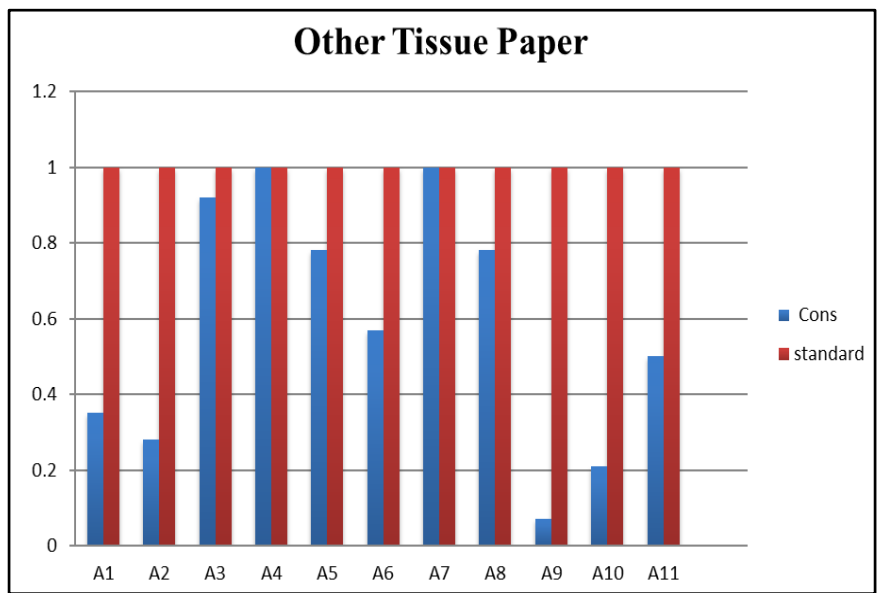

Fig 9: Shows the concentrations of chromium in the other tissue paper samples

The figure (9) shows the concentration of chromium of all samples of tissue paper of other type did not exceed standards and the highest concentration in the samples A7, A4 at a similar concentration 1ppm, and the lowest concentration in the sample A9 at a concentration of $0.07 \mathrm{ppm}$.

Concentrations of heavy metals are due to the main component of the manufacture of tissue paper, some napkins may be made from reuse of waste paper, and others are made from trees planted near roads or from trees grown near a source of pollution. The source of heavy metals is probably due to the water that used in the manufacture of tissue paper may be affected by heavy metal contamination.

\section{Conclusions}

The aim of this study to investigate the presence of some heavy metals in the different used tissue paper in the local market the result showed the different concentration of heavy metals in the tissue paper made outside country is containing less than other than Local made. 


\section{Acknowledgement}

I thank lap of Department Environmental Sciences, Faculty of

Engineering \&Technology, Sebha University Libya.

\section{References}

1. International Agency for Research on Cancer (IARC) Monographs - Cadmium. Lyon, France, 1993.

2. Jacobs JA, Testa SM. Overview of chromium (VI) in the environment: background and history. In: Guertin J, Jacobs JA, Avakian CP, editors. Chromium (VI) Handbook. Boca Raton, Fl: CRC Press; 2005, 1-22.

3. Gabby PN. Lead: in Mineral Commodity Summaries. Reston, VA: U.S. Geological Survey, 2006.

4. Gabby PN. "Lead." Environmental Defense "Alternatives to Lead-Acid Starter Batteries," Pollution Prevention Fact Sheet, 2003.

5. U.S. EPA. Environmental Criteria and Assessment Office. Cincinnati, OH: United States Environmental Protection Agency; Integrated Risk Information System (IRIS), 1992.

6. German Environmental Survey (Ger ES III): environmental pollutants in blood of the German population, 1998

7. Becker K, Kaus S, Krause C, Lepom P, Schulz C, Seiwert M. Seifert B Int J Hyg Environ Health. 2002; 205(4):297-308

8. Fergusson JE. editor. The Heavy Elements: Chemistry, Environmental Impact and Health Effects. Oxford: Pergamon Press, 1990.

9. Tchounwou PB, Wilson B, Ishaque A. Important considerations in the development of public health advisories for arsenic and arsenic-containing compounds in drinking water. Rev Environ Health. 1999; 14(4):211229.

10. Wittman R, Hu H. Cadmium exposure and nephropathy in a 28-year-old female metals worker. Environ Health Perspect. 2002; 110:1261.

11. George D, Florence E. Pall'ys industrial hygiene and toxicology, Vol 2A Toxicology. 3rd Edition. Awiley Inter Science Publication. New York, 1981.

12. Wilson B, Pyatt FB. Heavy metal dispersion, persistence, and bioaccumulation around an ancient copper mine situated in Anglesey. UK. Ecotoxicologyand Environmental Safety. 2007; 66:224-231.

13. Reilly C. metal contamination of food. Applied Sci. Publishers. Ltd. London, 1980.

14. NTP (National Toxicology Program). $10^{\text {th }}$ Report on carcinogens. U.S. Department of Health and Human Services, Public Health Service, Washington, DC, 2002.

15. Tomasevic M, Rajsic S, Dordevic DS. Heavy metals accumulation in tree leaves from urban areas. Environ Chem Lett. 2004; 2:151-154.

16. Nott JA, Hagstar WJ. Cadmium and the phosphate granules in Littorina. J. Mar. Biol. Assoc. UK. 1989; 69:219-227.

17. Thomas GS, Williams MS. Chemistry of the environment, $2^{\text {nd }}$ Prentis Hall of India, New Delhi, 2004, 319-325. 